\title{
INCIDENCE OF CENTRAL NERVOUS SYSTEM TUMORS IN PATIENTS HOSPITALIZED AT SPLIT UNIVERSITY HOSPITAL CENTRE DURING A TEN-YEAR PERIOD (JANUARY 1, 2004 - DECEMBER 31, 2013)
}

\author{
Maja Mizdrak ${ }^{1}$, Gordan Džamonja ${ }^{2}$ and Petar Filipović Grčić
}

${ }^{1}$ University of Split, School of Medicine, Split, Croatia; ${ }^{2}$ University Department of Neurology, Split University Hospital Centre, School of Medicine, University of Split, Split, Croatia

SUMMARY - The aim was to evaluate the incidence and characteristics of central nervous system tumors in patients hospitalized at the Department of Neurology, Split University Hospital Centre, during a 10-year period. The study included data on 859 patients with the diagnosis of central nervous system (CNS) tumor. Diagnosis was based on the routine CNS neuroimaging methods (computed tomography/magnetic resonance imaging). Access to patient medical records provided demographic and clinical data, continued by collection of data on potential lethal outcome of patients at the Registrar's Office. The study was conducted at the Department of Neurology, Split University Hospital Centre, from January 1, 2004 to December 31, 2013. There were 448 male and 411 female patients. Median age at the diagnosis was 65 (range, 18-95) years. Primary CNS tumors were diagnosed in 527 patients, including 30 primary recurrent tumors, whereas 328 patients had metastatic tumors; in 4 cases, it was impossible to determine whether the tumor was a primary one or metastasis based on CNS neuroimaging. The primary tumors proved to be more common than the metastatic ones $\left(\chi^{2}\right.$-test, $\mathrm{p}<0.05$ ). Multiple tumor transplants were more common than solitary (211 vs. 117; the conclusion was made at a $95 \%$ level of confidence; $\chi^{2}$-test, $\left.p<0.05\right)$. The majority of metastases originated from the lung (bronchus and pleura cancer; $46.41 \% ; \chi^{2}$-test, $\mathrm{p}<0.05 ; 95 \% \mathrm{CI}$ ). The most common localization of CNS tumors was supratentorial. Based on the double-logarithmic model, we proved with statistical significance that there was an increase in the incidence of CNS tumors $(\mathrm{p}=0.001)$. The most common tumors studied were supratentorially localized meningiomas.

Key words: Central nervous system neoplasms; Spinal cord neoplasms; Neuroimaging; Magnetic resonance imaging; Meningioma

\section{Introduction}

Central nervous system (CNS) tumors are a unique, heterogeneous group of benign and malignant tumors $^{1}$. What makes them unique is that they all are malignant by localization, regardless of their malig-

Correspondence to: Gordan Džamonja, $M D, P h D$, University Department of Neurology, Split University Hospital Centre, Spinčićeva 1, HR-21000 Split, Croatia

E-mail: dzamonja.gordan@st.t-com.hr

Received October 19, 2015, accepted June 26, 2016 nant potential. Any expansive process inside the skull or spine can cause focal neurological deficit, quantitative disturbance of consciousness, or death ${ }^{1}$. Therefore, although they are not the most common neoplasms in the adult population, the consequences can be devastating, hence their importance ${ }^{2}$. The etiology of these tumors is still unknown. The proposed oncogenesis mechanism is considered to be an interaction of harmful environmental factors, hormonal influences, inherited abnormalities, and acquired genetic mutations ${ }^{3}$. Men, especially of older age, are affected more often 
than women ${ }^{1,4}$. However, meningiomas and acoustic neuromas are more common in women ${ }^{4}$. Furthermore, CNS metastatic tumors frequently occur in males as lung cancer; the most common origin of brain metastases is more frequent in males 5 . According to literature data, meningiomas are the most frequent type of brain tumor, followed by gliomas (among them, glioblastoma multiforme is most common) and pituitary tumors ${ }^{6}$. Recent epidemiological studies conducted among different populations show a steady increase in the incidence of these tumors in both sexes ${ }^{1,4}$. The increasing incidence and specific localization make CNS tumors one of the greatest public health and medical problems. The aim of this study was to investigate the morbidity of CNS tumors during a 10-year period for a population of patients 18 years of age or older who were treated at the Department of Neurology, Split University Hospital Center (UHC) from Split, Croatia. Split UHC is a medical institution that is the leading regional center for the entire area of the Split-Dalmatia County. According to the 2011 census, the Split-Dalmatia County has 455,242 inhabitants (352,351 older than 18 years), but Split UHC also treats a large number of patients from other parts of southern Croatia and neighboring Bosnia and Herzegovina, as well as many tourists during the summer tourist season.

\section{Subjects and Methods}

\section{Structure and subjects}

The research was performed at Department of Neurology, Split UHC. This was a historic prospective study. Data on patients with CNS tumors diagnosed during a 10-year period (January 1, 2004 to December $31,2013)$ were collected from the patient medical records. Data collection continued until May 31, 2014 regarding the potential lethal outcome in subjects according to the archives of the Administrative $\mathrm{Au}-$ thority in the Split-Dalmatia County (Split Statistics Office, Department of Personal Status of Citizens). Inclusion criterion was the diagnosis of CNS neoplasms confirmed by standard neuroimaging methods (computed tomography $[\mathrm{CT}] /$ magnetic resonance imaging [MRI]). In most cases, it was sufficient to classify tumors according to their assumed histology. There were no data on definitive diagnosis based on biopsy. Patients were included in the study when the diagnosis of CNS tumor was made but it was impossible to precisely diagnose tumor type (primary or metastatic), or if this information was missing. Exclusion criteria were neuroradiological diagnosis of vascular malformation, hygromas, or cysts that imitated CNS neoplasms on radiological images or during clinical presentation. Another exclusion criterion was the diagnosis of CNS tumor outside the study period, regardless of whether the patient was hospitalized during the observed period due to complications of disease or some other reason.

\section{Statistical analysis}

The data collected during the study were incorporated in the previously constructed database in Microsoft Excel 2010 and then processed in Statistica 10 (StatSoft Inc., Tulsa, OK, USA) using the $\chi^{2}$-test. The results were interpreted at a significance level of $\mathrm{p}<0.05$. The double-logarithmic model was chosen as the most optimal statistical model for answering the basic research question of whether an upward trend in the incidence of tumors of the CNS existed. The equation model is as follows: $Y_{t}=\beta_{0}{ }^{*} X_{t}{ }^{\beta 1}$, where $X$ is the time variable (the independent variable that has a continuous flow) and $\mathrm{Y}$ is the dependent variable that indicates the expected number of patients with development of tumors during the time unit $t$. On the basis of the $\mathrm{F}$-value in the analysis of variance (ANOVA) table, it was concluded that the double-logarithmic trend model was statistically significant at a confidence level of $95 \%(\mathrm{p}=0.001)$.

\section{Results}

Of the total of 26,805 patients treated at the Department of Neurology, Split UHC from the beginning of 2004 until the end of 2013, 859 patients were included in the study; there were 448 (52.15\%) male and 411 (47.85\%) female patients. We found no statistically significant difference in the overall incidence of CNS tumors ( $\chi^{2}$-test, $\mathrm{p}=0.0507$ ) between the two genders. The median age at tumor presentation was 65 (range, 18-95) years. The most common age of patients at the time of diagnosis was 66 years (32 patients).

In 527 patients, primary CNS tumor was diagnosed and, among these, 30 had a primary recurrent/ residual tumor, which means that the tumor appeared 
Table 1. Central nervous system tumors diagnosed at the Split University Hospital Center from 2004 to 2013

\begin{tabular}{|c|c|c|c|c|c|c|c|c|c|c|c|c|}
\hline 䒕 & 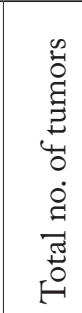 & 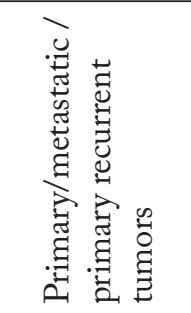 & 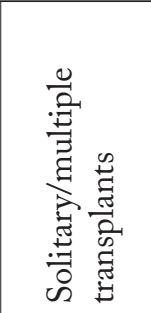 & 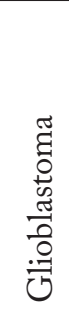 & 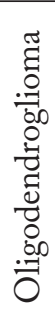 & 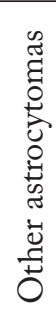 & 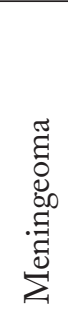 & 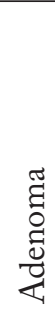 & 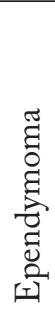 & 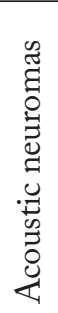 & $\frac{*_{\vec{D}}^{ \pm}}{\frac{ \pm}{5}}$ & 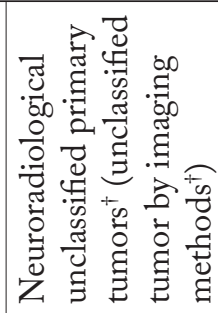 \\
\hline 2004 & 57 & $32 / 24 / 1$ & $12 / 12$ & 6 & 0 & 3 & 12 & 1 & 0 & 0 & 2 & 8 \\
\hline $2005^{\ddagger}$ & 88 & $52 / 28 / 4$ & $10 / 18$ & 7 & 0 & 5 & 19 & 1 & 1 & 0 & 2 & 17 \\
\hline 2006 & 91 & $56 / 31 / 4$ & $9 / 22$ & 12 & 1 & 5 & 22 & 1 & 1 & 0 & 2 & 12 \\
\hline 2007 & 82 & $38 / 41 / 3$ & $20 / 21$ & 8 & 1 & 5 & 18 & 5 & 0 & 0 & 1 & 0 \\
\hline 2008 & 98 & $56 / 41 / 1$ & $15 / 26$ & 14 & 0 & 8 & 22 & 3 & 0 & 0 & 3 & 6 \\
\hline 2009 & 78 & $47 / 28 / 3$ & $13 / 15$ & 12 & 2 & 4 & 14 & 0 & 1 & 2 & 1 & 11 \\
\hline 2010 & 65 & $42 / 19 / 4$ & $5 / 14$ & 7 & 0 & 5 & 15 & 3 & 0 & 1 & 2 & 9 \\
\hline 2011 & 111 & $67 / 43 / 1$ & $9 / 34$ & 14 & 2 & 5 & 28 & 2 & 1 & 1 & 3 & 11 \\
\hline 2012 & 97 & $53 / 40 / 4$ & $13 / 27$ & 14 & 0 & 7 & 19 & 3 & 1 & 4 & 0 & 5 \\
\hline 2013 & 92 & $54 / 33 / 5$ & $11 / 22$ & 11 & 1 & 6 & 24 & 0 & 1 & 3 & 2 & 6 \\
\hline Total & 859 & $497 / 328 / 30^{\S}$ & $117 / 211^{\|}$ & 105 & 7 & 53 & 193 & 19 & 6 & 11 & 18 & 85 \\
\hline
\end{tabular}

Overall annual incidence of tumors is shown together with radiological presentation of certain tumor types; "the 'Other' category includes rare types of primary CNS tumors (lipoma, angioma, PNET, pinealoma, ganglioma, lymphoma); ${ }^{\dagger}$ the 'neuroradiological unclassified primary tumors' category includes de novo originated primary CNS tumors for which it was impossible to determine tumor subtype using neuroimaging methods CT/MRI; ;in four patients (2005), on the basis of radiological presentation, it was impossible to distinguish whether it was a primary or metastatic tumor, or data were incomplete; ${ }^{\S} \chi^{2}, \mathrm{p}<0.05 ; \| \chi^{2}, \mathrm{p}<0.05$

again after being previously treated at the same site or its residue remained there. There were $328(38.18 \%)$ patients with metastatic tumors. In four $(0.47 \%)$ patients, it was impossible to distinguish based on radiological presentation whether the tumor was a primary or metastatic tumor, or if the data were incomplete. Interval assessment determined that the primary CNS tumors were significantly more frequent than metastases $\left(\chi^{2}\right.$-test, $\left.\mathrm{p}<0.05\right)$. The conclusion was made at a confidence level of $95 \%$. Out of 328 patients with metastatic tumors, 117 had solitary transplants and 211 had multiple transplants $\left(\chi^{2}\right.$-test, $\left.\mathrm{p}<0.05\right)$. According to our results, the most common primary origin of metastatic CNS tumors was the lung (bronchial and pleural tumors; 46.41\%; $\chi^{2}$-test, $\mathrm{p}<0.05$ ).

In our study, the most common presenting sign of CNS tumors was muscle weakness ( $n=387)$, followed by epileptic seizures $(n=175)$, headache $(n=136)$, various types of speech disorders $(n=121)$, ataxia $(n=91)$, quantitative and qualitative disorders of consciousness $(n=86)$, visual disturbances $(n=68)$, nausea with vomiting and dizziness $(n=68)$, pain in lumbar spine $(n=32)$, and memory disorders $(\mathrm{n}=28)$. We also recorded some rare presenting signs and symptoms such as hyposmia, dysphagia, weight loss, dyscalculia, dyslexia, and incontinence. In 31 patients, the tumor was diagnosed accidentally after patients were referred to the hospital for suspicion of Parkinson's disease or stroke.

There were 806 intracranial $\left(\chi^{2}\right.$-test, $\mathrm{p}<0.05 ; 95 \%$ $\mathrm{CI})$ and 52 spinal tumors. In one patient, the tumor affected both the brain and the spinal cord.

In our research, the most common type of primary CNS tumor was meningioma (Table 1). They were found in 193 patients (36.62\% of all primary CNS tumors). Among them, 104 were females and 89 were males. There was no statistically significant difference in meningioma morbidity according to gender $\left(\chi^{2}\right.$-test, $\mathrm{p}>0.05 ; 95 \% \mathrm{CI})$. The second most common tumor was glioblastoma multiforme, which was diagnosed in 105 patients (19.92\%; 57 males and 48 females) and yielded no statistical significance in morbidity rates between sexes ( $\chi^{2}$-test, $\left.p>0.05 ; 95 \% \mathrm{CI}\right)$. Other types of astrocytomas were the third most common tumor type. In 85 cases, it was impossible to determine the 
Table 2. Comparison of real and expected numbers of patients for each year

\begin{tabular}{|l|l|l|l|}
\hline \multicolumn{3}{|l|}{$Y_{t}=\beta_{0}{ }^{*} X_{t}^{\beta 1}$} \\
\hline$Y_{e a r}{ }^{\beta}$ & $\begin{array}{l}\text { Real no. } \\
\text { of patients } \\
\text { (n) }\end{array}$ & $\begin{array}{l}\text { Expected } \\
\text { no. of } \\
\text { patients }\end{array}$ & $\begin{array}{l}\text { Calculated } \\
\text { difference between } \\
\text { real and expected } \\
\text { no. of patients }\end{array}$ \\
\hline $2004(0)$ & 57.00 & $75.47^{\dagger}$ & -18.47 \\
$2005(1)$ & 88.00 & 77.62 & 10.38 \\
$2006(2)$ & 91.00 & 79.83 & 11.17 \\
$2007(3)$ & 82.00 & 82.09 & -0.09 \\
$2008(4)$ & 98.00 & 84.43 & 13.57 \\
$2009(5)$ & 78.00 & 86.84 & -8.84 \\
$2010(6)$ & 65.00 & 89.31 & -24.31 \\
$2011(7)$ & 111.00 & 91.85 & 19.15 \\
$2012(8)$ & 97.00 & 94.47 & 2.53 \\
$2013(9)$ & 92.00 & 97.16 & -5.16 \\
\hline
\end{tabular}

*ANOVA table F-value (162.67); $\mathrm{p}=0.001 ;{ }^{\dagger} \bigcap_{0} 75.46798$ (indicates the expected number of patients during the first year of observation [2004]); $\beta 1=1.02847$ (means that the expected number of patients will increase by $1.02847 \%$ with every progression of the time of observation for $1 \%) ;{ }^{\ddagger}$ numbers $(0-9)$ in parentheses indicate statistical mark for each year 2004-2013.

subtype of primary tumor by standard neuroimaging diagnostic methods.

Of the total of 859 patients, 49 died during hospitalization and 425 patients were referred to the Department of Neurosurgery, Split UHC or Zagreb UHC for neurosurgery procedures. The remainder of patients were discharged to home care $(n=192)$ or transferred to another university department/department of Split UHC for additional treatment (University Department of Internal Medicine: $n=88$; Oncology Department: $n=77$; Central Intensive Care Unit: $\mathrm{n}=8$; Department for Infectious Diseases, Psychiatric, or Urology Department: $\mathrm{n}=20$ ). To assess the survival rate of patients included in our study, we continued our research by sending a request to the Office of the State Administration in the Split-Dalmatia County, Split Register Office, Department of Personal Status of Citizens (referred to hereafter as Split Register Office) to allow us to check the death register until May 31,2014 . We found that 426 of 859 (49.59\%) patients died between January 1, 2004 and May 31, 2014; 266 of them had primary tumors diagnosed and $160 \mathrm{had}$ metastatic tumors diagnosed. Then, we analyzed three separate years for survival rates. In 2004, there were a total of 57 patients. Ten years after the diagnosis had been made (2014), 22 of them were still alive, which means that their 10 -year survival rate was $38.59 \%$. Of the 78 patients diagnosed in 2009, 40 patients died by May 31,2014, i.e. their 5-year survival rate was $48.72 \%$. Finally, 57 of 92 patients with the diagnosis set in 2013 (61.96\%) were alive 1 year after the diagnosis.

Finally, the results of our study confirmed the increasing trend in the incidence of CNS tumors in the Split-Dalmatia County during the 10-year observation period. Although the number of new cases showed an irregular increase for each subsequent year, by using the double-logarithmic model based on the real data collected, estimated numbers of new cases were calculated for each year (Table 2). In the second column in Table 2, the numbers of newly diagnosed CNS tumors are shown by year. The third column in Table 2 contains the expected values of the estimated trend model, whereas the fourth column shows residual values, i.e. difference between the real and expected values.

\section{Discussion}

There was an increasing trend in the incidence of CNS tumors in patients hospitalized at the Department of Neurology, Split UHC from January 1, 2004 to December 31, 2013 (Fig. 1). The increase in the CNS tumor incidence was also observed in developed countries (Australia/New Zealand, Europe, North America), but a low incidence was observed in Africa ${ }^{5}$.

This finding raises the question of its cause; is it artificial or real? It can be explained simply as a consequence of the general social progress in developed countries, but several factors must be taken into consideration. The first factors are better sensitivity and greater power of the new generation of CT/MRI devices, which enable higher spatial resolution when analyzing nervous tissue and blood vessels ${ }^{5}$. Other factors playing important roles include wider accessibility of neuroradiological units, easier access to medical health care, and a growing number of neurologists in developed countries (better recognition of clinical symptoms of CNS tumors) ${ }^{5}$. However, it seems quite plausible that the verified increased incidence of CNS tumors might be real and related to the modern way of living and rapid environmental changes. 


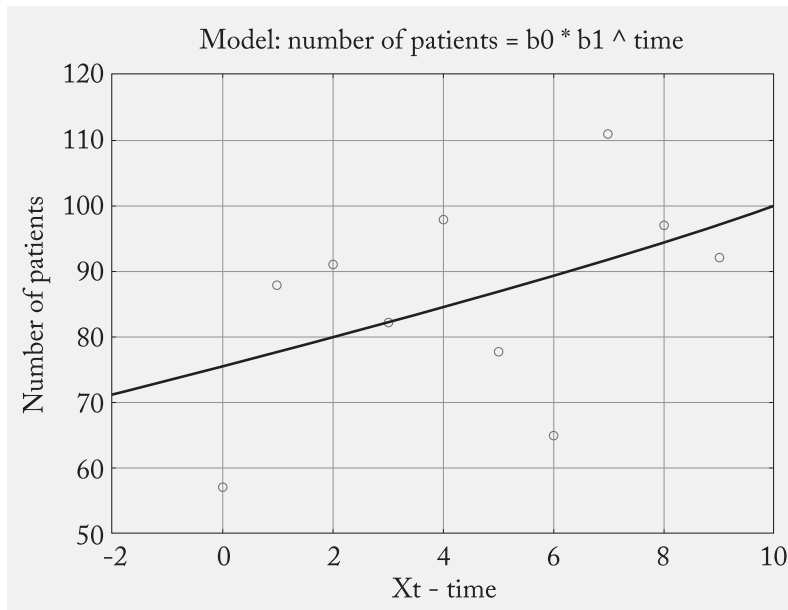

Fig. 1. Graphic display of real and expected values of morbidity associated with CNS tumors at Split University Hospital Center from January 1, 2004 to December 31, 2013. The line indicates the trend and the circles indicate real values.

During the 10-year period observed, the most common tumors of the CNS were primary tumors. In our study, they were almost two-times more frequent than secondary tumors; this is not in accordance with the majority of literature reports, where metastatic tumors are referred to as being 10-times more frequent than other tumors ${ }^{7}$. The possible explanations for this finding might be that primary tumors of other localizations (e.g., lung cancer) are treated at other departments, and if they progress to CNS, then these metastases are recorded somewhere else.

Meningioma ( $n=193$ ) was the most common type of primary tumor; its highest frequency was recorded in 2011, when it was diagnosed 28 times, and its lowest frequency was in 2004, when 12 meningiomas were diagnosed. It was followed by glioblastoma multiforme $(n=105)$. Completely different results were presented in an epidemiological study that investigated the incidence of CNS tumors in the Karlovac area (central part of Croatia) during the 1995-2010 period; it was demonstrated that glioblastoma multiforme was the most common primary neoplasm of the CNS and was almost three-times more frequent than meningioma ${ }^{8}$. Also, secondary tumors were cited as the most common type of tumors of the CNS in the same study.

The results of a research conducted from 1996 to 2004 in Varaždin County (northern part of Croatia) coincided with our results because they found primary
CNS tumors to be more common than secondary ones $^{9}$. The same was reported in the epidemiological study (1974-2001) conducted in the region of Labin (Istra County $)^{10}$.

In a study performed in neighboring Bosnia and Herzegovina (where the capital is Sarajevo), a 10-year period (1990-1999) was studied; the results obtained were also consistent with ours, reporting the primary CNS tumors being most common ${ }^{11}$.

The obvious differences in the results of various studies emphasize the importance of continuous search for different risk factors, particularly environmental ones, that might be related to the CNS tumor oncogenesis.

The Central Brain Tumor Registry of the United States (CBTRUS) in statistical reports from 2006 to 2010 also states that meningioma is the most common primary neoplasm of the CNS, with an incidence of 7.44/100,000 compared with 3.19/100,000 for glioblastoma multiforme ${ }^{6}$.

In our study, the mean age at tumor diagnosis was $62.94 \pm 14.62$ years. In Puerto Rico, it was 52.4 years, in Georgia (Eurasian country) it was $48.9 \pm 18.1$ years, and in the United States it was 79.22 years ${ }^{12-14}$. The observed age differences are explained as a result of differences in the organization of health care, i.e. development and accessibility of health care, as well as the standard of living and the average life span.

It is very important to analyze the average age at CNS tumor diagnosis because the responsiveness of brain tumors to chemotherapy is age-dependent ${ }^{15}$. In vitro studies have shown the sensitivity of tumor cells to chemotherapeutics in seven of eight cases in patients younger than 50 years, whereas tumor cells in patients older than 50 responded to therapy only in one of eight of cases ${ }^{15}$.

In our study, the ratio of affected men and women was almost the same, with $52.15 \%$ of male compared with $47.85 \%$ of female. These results correspond to the findings obtained by a group of scientists who explored the region of Gorski Kotar (western Croatia) and the neighboring islands during the 1977-2000 period $^{16}$.

Interestingly, while examining the literature, we found the research by Murray et al., which suggests that tumors of the CNS are more common in women than in men $(58 \% \text { vs. } 42 \%)^{14}$, as well as the study by Bhurgri et al., which, in contrast, indicated that men were affected more often than women (ratio, 1.6:1) ${ }^{4}$. In 
our study, no statistically significant sex differences were found in the overall and specific morbidity.

The results of the analysis of metastatic tumors showed that multiple transplants were more common than solitary transplants. Their predominant origin was the lung (bronchial and pleural tumors), followed by breast cancer and malignant melanoma, which is fully in line with the findings reported in the literature ${ }^{17-19}$. Lung tumors metastasize very early, within the first 2 years, and $10 \%$ of patients with small cell lung carcinoma already have CNS metastases at the time of diagnosis of the primary tumor ${ }^{20}$. It is estimated that in $30 \%$ of patients with cancer of some other site, the cancer will eventually spread to the brain ${ }^{21,22}$. Data in the Cancer Registry of the Croatian Institute of Public Health show that the mean incidence of primary CNS neoplasms from 2004 to 2011 in Croatia was 13.5/100,000 (data for 2012 and 2013 are not yet available), and according to our results for the same period it was $11.07 / 100,000$, which corresponds to the current trends in the world $(11.5 / 100,000)^{23}$.

Future studies of this issue should improve the understanding of risk factors important for the origin of CNS tumors and explore the effect of active and passive smoking, effects of alcohol consumption, effects of exposure to radiation, effects of cell phone usage, effects of diet containing genetically modified organisms, and many others. However, because the majority of the patients included in our study had arterial hypertension, hyperlipidemia, or diabetes, or a combination of these, future investigations should consider the influence of the metabolic syndrome or its components in human carcinogenesis, especially when acting through systemic oxidative stress with increased values of free fatty acids and free radical oxygen species ${ }^{24}$.

\section{Study limitations}

The main limitation of this study was the possibility of whether the diagnosis of CNS tumors during the observed period may have been made in the Department of Neurology, Split UHC. More precisely, we believe that the incidence of CNS tumors observed during the 10-year period in the catchment population of the Split UHC as the leading regional health center could be even higher than that displayed by this research. The explanation lies in the fact that some CNS tumors were diagnosed in other institutions or in the emergency neurology ward, which then referred these patients to other departments for further treatment or to home care without being admitted to the Department of Neurology. However, because of the long, 10year period of observation, the possibility of making errors when assessing CNS tumor incidence was minimized. Another drawback is related to the retrospective character of the study and the fact that tumors were classified according to their neuroimaging features and presumed histology, not on histopathologic examination. Finally, the possible limiting factor is that data were obtained from the Split Registry Office. We found whether a particular patient from our study was alive, but we could not obtain the date of death, which is necessary to establish the exact length of survival with a particular diagnosis.

\section{Conclusion}

Based on the double-logarithmic model, we proved with statistical significance that there was an increase in the incidence of CNS tumors observed during the 10 -year study period ( $\mathrm{p}=0.001)$. The most common tumor in our study was supratentorially localized meningioma.

\section{References}

1. Vrdoljak E, Šamija M, Kusić Z, Petković M, Gugić D, Krajina Z. Klinička onkologija (textbook). Zagreb: Medicinska naklada; 2013. (in Croatian)

2. Davis FG, McCarthy BJ, Berger MS. Centralized databases available for describing primary brain tumor incidence, survival, and treatment: Central Brain Tumor Registry of the United States; Surveillance, Epidemiology, and End Results; and National Cancer Data Base. Neuro Oncol. 1999;1:205-11. doi: 10.1093/neuonc/1.3.205

3. Chahal HS, Stals K, Unterländer M, Balding DJ, Thomas MG, Kumar AV, et al. AIP mutation in pituitary adenomas in the $18^{\text {th }}$ century and today. N Engl J Med. 2011;364:43-50. doi: 10.1056/NEJMoa1008020

4. Bhurgri Y, Bhurgri H, Kayani N, Ahmad R, Usman A, Bhurgri $A$, et al. Trends and morphology of central nervous system malignancies in Karachi. Asian Pac J Cancer Prev. 2011;12: 2013-7.

5. Arora RS, Alston RD, Eden TO, Estlin EJ, Moran A, Geraci $\mathrm{M}$, et al. Are reported increases in incidence of primary CNS tumors real? An analysis of longitudinal trends in England, 1979-2003. Eur J Cancer. 2010;46:1607-16. doi: 10.1016/j. ejca.2010.02.007

6. Dolecek TA, Propp JM, Stroup NE, Kruchko C. CBTRUS statistical report: primary brain and central nervous system tu- 
mors diagnosed in the United States in 2005-2009. Neuro Oncol. 2012;14:1-49. doi:10.1093/neuonc/nos218

7. Lu-Emerson C, Eichler AF. Brain metastases. Continuum (Minneap Minn). 2012;18:295-311. doi: 10.1212/01.CON.0000413659.12304.a6

8. Jančić E, Cvitanović H, Miholović V, Kralj D, Hranilović B. Epidemiology of central nervous system tumors in Karlovac area (Croatia), 1995-2010. Coll Antropol. 2011;35:331-3.

9. Dobec-Meić B, Pikija S, Cvetko D, Trkulja V, Pazanin L, Kudelić $\mathrm{N}$, et al. Intracranial tumors in adult population of the Varazdin County (Croatia) 1996-2004: a population-based retrospective incidence study. J Neurooncol. 2006;78:303-10. doi: 10.1007/s11060-005-9100-2

10. Materljan E, Materljan B, Sepčić J, Tuskan-Mohar L, Zamolo G, Erman-Baldini I. Epidemiology of central nervous system tumors in Labin area, Croatia, 1974-2001. Croat Med J. 2004; 45:206-12.

11. Alajbegović A, Hrnjica M, Dimitrijević J, Zukić T, Bulić G, Ajanović Z, et al. [Central nervous system neoplasms in clinical data from the Neurology Clinic KCU in Sarajevo 1990-1999]. Med Arh. 2002;56:15-9. (in Croatian)

12. Surawicz TS, McCarthy BJ, Kupelian V, Jukich PJ, Bruner JM, Davis FG. Descriptive epidemiology of primary brain and CNS tumors: results from the Central Brain Tumor Registry of the United States, 1990-1994. Neuro Oncol. 1999;1:14-25. doi: 10.1093/neuonc/1.1.14

13. Gigineishvili D, Gigineishvili T, Tsiskaridze A, Shakarishvili R. Incidence rates of the primary brain tumours in Georgia a population based study. BMC Neurol. 2014;14:29. doi: 10.1186/1471-2377-14-29

14. Murray G, Jiménez L, Báez F, Colón-Castillo LE, Brau RH. Descriptive profile of surgically-confirmed adult central nervous system tumors in Puerto Rico. P R Health Sci J. 2009; 28:317-28.

15. Grant R, Liang BC, Page MA, Crane DL, Greenberg HS, Junck L. Age influences chemotherapy response in astrocytomas. Neurology. 1995;45:929-33.

doi: https://doi.org/10.1212/WNL.45.5.929
16. Tuskan-Mohar L, Materljan E, Jurjević A, Weiner-Crnja M, Willheim K, Antoncić I, et al. Epidemiology of primary central nervous system tumors in the Coast and Gorski Kotar County, Croatia, 1977-2000. Tumori. 2004;90:550-5.

17. Schouten L, Rutten J, Huveneers H, Twijnstra A. Incidence of brain metastases in a cohort of patients with carcinoma of the breast, colon, kidney, and lung and melanoma. Cancer. 2002; 94:2698-705. doi: 10.1002/cncr.10541

18. Kebudi R, Ayan I, Görgün O, Ağaoğlu FY, Vural S, Darendeliler E. Brain metastasis in pediatric extracranial solid tumors: survey and literature review. J Neurooncol. 2005;71:43-8. doi: 10.1007/s11060-004-4840-y

19. Chou YS, Liu CY, Chen WM, Chen PC, Wu HT, Shiau CY, et al. Brain, the last fortress of sarcoma: similar dismal outcome but discrepancy of timing of brain metastasis in bone and soft tissue sarcoma. J Surg Oncol. 2011;104:765-70. doi:10.1002/jso.22011

20. Castrucci W, Knisely J. An update on the treatment of CNS metastases in small cell lung cancer. Cancer J. 2008;14:138-46. doi: 10.1097/PPO.0b013e318172d6e1

21. Fox BD, Patel A, Suki D, Rao G. Surgical management of metastatic sarcoma to the brain: clinical article. J Neurosurg. 2009;110:181-6. doi: 10.3171/2008.4.17505

22. Salvati M, D'Elia A, Frati A, Santoro A. Sarcoma metastatic to the brain: a series of 35 cases and considerations from 27 years of experience. J Neurooncol. 2010;98:373-7. doi: 10.1007/s11060-009-0085-0

23. Hrvatski zavod za javno zdravstvo (Croatian Institute of Public Health), Registar za rak (Cancer Registry), Izvješća (Reports), (2004-2011), Zagreb; 2012 (cited 2014 Jun 6) available at: http://hzjz.hr/sluzbe/sluzba-za-epidemiologiju/odjel-za-nadzor-i-istrazivanje-ne-zaraznih-bolesti/odsjek-za-zlocudnebolesti-s-registrom-za-rak/. (in Croatian)

24. Matsuda M, Shimomura I. Increased oxidative stress in obesity: implications for metabolic syndrome, diabetes, hypertension, dyslipidemia, atherosclerosis, and cancer. Obes Res Clin Pract. 2013;7:e330-41. https://doi.org/10.1016/j.orcp.2013.05.004 


\section{Sažetak \\ INCIDENCIJA TUMORA SREDIŠNJEGA ŽIVČANOG SUSTAVA \\ U BOLESNIKA HOSPITALIZIRANIH U KLINIČKOM BOLNIČKOM CENTRU SPLIT OD 1. SIJEČNJA 2004. DO 31. PROSINCA 2013. GODINE}

\section{Mizdrak, G. Džamonja i P. Filipović Grčić}

Cilj je bio ispitati incidenciju i značajke tumora središnjega živčanog sustava (SŽS) u bolesnika hospitaliziranih u Klinici za neurologiju Kliničkoga bolničkog centra Split u desetogodišnjem razdoblju. U razdoblju od 1. siječnja 2004. do 31. prosinca 2013. godine u Klinici za neurologiju je bilo hospitalizirano 859 bolesnika s tumorima SŽS. Dijagnoza se temeljila na nalazima slikovnih dijagnostičkih metoda (kompjutorizirana tomografija/magnetska rezonancija mozga). Demografski i klinički podaci su prikupljeni iz povijesti bolesti bolesnika. S ciljem određivanja stope smrtnosti studija je nastavljena i prikupljanjem podatka iz Matične knjige umrlih. U promatranom razdoblju ukupno je bilo 448 muškaraca i 411 žena s tumorima SŽS. Prosječna dob postavljanja dijagnoze je bila 65 godina. Primarni tumori SŽS su dijagnosticirani u 527 bolesnika, uključivo 30 bolesnika s recidivirajućim primarnim tumorima, a 328 bolesnika je imalo metastatske tumore. U 4 bolesnika nije bilo moguće odrediti je li se radilo o primarnom tumoru ili metastazi na temelju neuroradioloških nalaza. Primarni tumori su bili češći od metastatskih $\left(\chi^{2}\right.$-test, $\left.p<0,05\right)$. Multiple presadnice su bile češće od solitarnih (211 prema $117,95 \% \mathrm{CI} ; \chi^{2}$-test, $\left.\mathrm{p}<0,05\right)$. Većina metastaza je bila podrijetlom iz tumora pluća $\left(46,41 \% ; \chi^{2}\right.$-test, $\left.p<0,05 ; 95 \% \mathrm{CI}\right)$. Najčešći su bili supratentorijski lokalizirani tumori SŽS. Primjenom dvostruko-logaritamskog modela pokazali smo da postoji statistički začajan porast incidencije tumora SŽS u ispitivanom razdoblju. Od svih tumora SŽS najčešći su bili suptratentorijski meningeomi.

Ključne riječi: Središnji živčani sustav, tumori; Kralježnična moždina, tumori; Neurološko snimanje; Magnetska rezonancija, snimanje; Meningeom 